\title{
Whose Land is it Anyway? Contesting Urban Fringe Nature-based Tourism and Recreation in Western Australia
}

\author{
MICHAEL HUGHES, MARIAN TYE and ROY JONES
}

\begin{abstract}
A bstract: Urban fringe natural areas on public land are important resources for tourism and recreation use. However these contested areas are al so in demand for a range of other land uses. How the land is managed can strongly influence opportunities for nature-based tourism and recreation, and the benefits that these bring to participants and host communities. This paper examines the case of tourism and recreation access to the forested urban fringe of Perth, Western Australia (WA) using a typology of land occupancy and management priorities originally devised for private land use. A review of legislation and policy relating to tourism and recreation access to land in WA was conducted. Tourism and recreation groups and land managers associated with access to the Perth urban fringe natural areas were interviewed regarding their perceptions of land access management. Most land in the WA study area is publically owned and is therefore technically accessible to the public. In regions dominated by multiple private land owners such as Europe and the UK, varying approaches to land-use management may be classified according to a predictable land occupancy typology that tends to be consistently applied. By contrast, the single public land holder in this area of WA, the state government, lacks consistency in its approach to recreational and tourist access to land. This creates both public and governmental uncertainty and confusion regarding where and how land may be accessed on the Perth urban fringe.
\end{abstract}

Keywords: Iand access management; land occupancy; urban fringe; natural area; Western Australia.

\section{Introduction}

This paper examines themanagement of tourist and recreational access to public land in Western Australia within the broader context of land-use management regimes. In particular, this paper considers claims by WA recreation and tourism advocates that public access to the peri-urban areas of the state's capital city is being significantly reduced despitethegrowing demand for this type of access to public land. This reduction of access is seen by these groups to have important consequences for thefuture of nature-based tourism and recreational activity and opportunities in this region.
Nature-based experiences are a significant component of tourism and recreation activity gl obally (Hughes and Carlsen 2009; Jennings 2007). In particular, fringeareas under natural vegetation and adjacent to urban development arean important and accessible resource for nature based tourism and recreation (Mann et al. 2010; N ewsome et al. 2002). However, the expansion of urban areas and the growth in urban populations are generating increased pressures for the provision of a range of resources and uses on theselocations (Garrod et al. 2006; Millward 1991; Urquhart et al. 2012). According to Holmes (2006), land use patterns on the urban fringearecomplex because of therange and type of occupancy modes that occur in these

MICHAEL HUGHES is Senior Lecturer at the School of Marketing, Curtin University, GPO Box U1987, Perth, WA 6845, A ustralia. e-mail: m.hughes@curtin.edu.au

MARIAN TYE is Director, Centre for Sport Recreation Research, Curtin University, Australia. e-mail: M.Tye@curtin.edu.au ROY JONES is Emeritus Professor at the Faculty of Humanities, Curtin University, Australia. e-mail: R.Jones@curtin.edu.au 
areas. Holmes (2006) identified key 'land occupance modes' associated with the urban fringein which the broad land-use categories of production, consumption and protection existin closeproximity. In this context, rapid urban expansion, combined with associated increased demand for outdoor tourism and recreation activity on the urban fringe, has exacerbated the land-use conflicts that are, in any case, characteristic of such areas (Hughes and Ingram 2009; Laing et al. 2008a).

Many Scholars (Jenkins and Prin 1998; M cl ntyreet al. 2001; U rquhart et al . 2012) observed that there is a considerable body of research into public access to land for various forms of recreation and tourism. Furthermore, Butler et al. (1998), Hultman et al. (2011) and Urquhart et al. (2012) consider that peri-urban and rural tourism have received greater recognition by managers and policy-makersover recent decades, in linewith their growth, as a significant and valuable land-use. While there has been a shift towards such multifunctional land-use, how this is operationalized depends significantly on who manages the land and what they prioritize in terms of thethree occupancy modes of production, consumption and protection (Garrod et al. 2006).

In this context, although public access to periurban areas for recreation and tourism is generally reported to have increased priority in developed nations, it is still often considered as an imposition by land managers and owners. A range of issues may contribute to this including landowner and manager sense of exclusive ownership, concerns about public liability and theordering of land-use priorities that places tourismand recreation below other preferred uses (Millward 1991). For example, although government management of publicland includes recognition of tourism and recreation as a legitimate use, in practice, management tends to favour productive values that include timber extraction, mining and agriculture, as well as conservation (Pigram and Jenkins 1999; Haukeland 2010). This often clashes with theWestern tradition in rural areas of freeaccess to publicland for various uses including recreation (Williams 2001).

In this vein, U rquhartetal. (2012) developed a typology of land-use functionality based on a considerablebody of published research in theUK, US and Europe. This typology is based on management of woodlands as areas in significant demand for a range of uses by land managers and the public, including tourism and recreation. Table 1 summarizes the four different occupancy mode typesidentified and their woodland management priorities as identified by U rquhart et al. (2012).

Table 1. Typology of Woodland 0 ccupance M odes from U rquhart et al . (2012)

\begin{tabular}{|l|l|}
\hline Occupance M ode & \multicolumn{1}{|c|}{ Core Attributes } \\
\hline Multi-functional & $\begin{array}{l}\text { Entrepreneurial approach that } \\
\text { includes timber production, } \\
\text { conservation, public access for } \\
\text { recreation and tou rism. Ind udes a } \\
\text { profit moti ve. }\end{array}$ \\
\hline Individualist & $\begin{array}{l}\text { Strong emphasis on exclusive } \\
\text { property rights. Tend to focus on } \\
\text { extractive uses and provision of } \\
\text { ecosystem services. Against public } \\
\text { access. }\end{array}$ \\
\hline Hobby & $\begin{array}{l}\text { Strong emphasis on protecting } \\
\text { natural habi tat. Wary of public } \\
\text { access due to potential impacts on } \\
\text { nature values. }\end{array}$ \\
\hline The Custodian & $\begin{array}{l}\text { Maintain natural resource for future } \\
\text { generations. Includes extractive uses } \\
\text { and conservation. Wary of public } \\
\text { access due to risk and liability } \\
\text { concerns. }\end{array}$ \\
\hline
\end{tabular}

Source: Authors

Thesevarious modes of land occupancy reflect varying levels of acceptance of access for recreation and tourism in a complex setting of land ownership and management. In Urquhart et al.'s (2012) particular case, this variation is generated by the patchwork of distinct private tenures which are owned and managed by individuals for a range of purposes. Thepreponderance of privately owned land in the UK and Europe dominates the debate regarding tourism and recreation access in these regions (Garrod et al. 2006). By contrast, given the relatively large proportion of publicly owned, naturally vegetated land in Western A ustralia, as compared with the UK, Europe and the United States, the management of access to this land is generally dominated by government (Hall 2011; Hughes and Ingram 2010). Perhaps because of this, 
Urban Fringe and Nature-based Tourism: Hughes et al.

there is currently no specific legislation in A ustralia that directly defines rights of access to land for outdoor tourism and recreation, as is now the case in the UK, continental Europe and other countries (Hughes et al. 2010). This is because public land is morelikely to beseen as generally accessibleto the public, on whosebehalf the government manages theland.

However, even with the government as the single, dominant land manager, there is still a variable and often conflicting approach to the management of public land. This is characteristically based on differences within and between government departments (Hall 2011). Furthermore, there is still alimited supply of such land whilepressurefrom competing modes of access to it is increasing. Sincegovernment, for economic and environmental reasons respectively, tends to prioritizeland uses associated with production and conservation, this can constrain levels of access for non-productivist modes of land-use, including tourism and recreation. As a result, opportunities for nature-based tourism and recreation on the urban fringemay berestricted while growing urban populations, with increased disposable time and income, are fuelling a growing demand for tourism and recreation access (Williams and Shaw 2009).

This paper examines the case of tourism and recreation accessto theurban fringe of Perth, Western A ustralia with reference to the typologies of land occupancy described by U rquhart et al. (2012) and Holmes (2006). The metropolitan area of Perth (population 1.7 million) is growing rapidly with an associated increase in demand for nature-based tourism and recreation in the publicly owned and government managed natural areas adjacent to the city's inland eastern fringe. Themajority of land in this region is managed by various arms of the Western A ustralian State Government for a range of purposes. Access for tourism and recreation is seen by recreation user groups to be increasingly restricted in favour of other public land occupancy modes. This paper examines the public land management context of thePerth urban fringeand its relationship with nature-based recreation and tourism access management.

\section{D arling Range Tourism and Recreation}

The Darling Range is an area of hills, woodlands, forests, rivers, farms and water bodies (mainly reservoirs and dams for stock) situated along theeastern fringe of themetropolitan area of Perth, the capital of Western A ustralia (WA). The rangecomprises about $30,000 \mathrm{~km}^{2}$ of various land tenures and jurisdictions in the southwest of WA (Williamson and Mitchell 2001). A bout 65\% of the area is public land, managed by the WA State Government for a range of land uses including nature conservation, timber production, drinking water catchment, mining and tourism and recreation (Conservation Commission 2010). Public land in the Darling Range varies in terms of type and extent of public access, depending on the applied management regime(Table3). Privateland in theregion is used for various types of agriculture, semi-rural retreats urban development and some mining.

Over the past 60 years, the population of the Perth M etropolitan A rea has grown considerably from approximately 310,000 in 1950 to more than 1.7 million in 2012 (Weller 2009; ABS 2012). The amount of disposableincomeand timeavailableto thepopulation has also increased over this period. Consequently, the Darling Range, as Perth's inland 'playground', has experienced an increase in demand for its resources, including access for tourism and recreation (Advisory Committee on Purity of Water 1977; Williamson and Mitchell 2001; Jennings 2007; Ingram and Hughes 2009). The metropolitan area and associated urban corridors have expanded along the coastal plain. Consequently, the adjacent areas of the Darling Rangeare in demand for a range of recreation and tourism activities. This has resulted in an increasingly complex land-use management environment within which competing land-uses vie for a limited area of availableland. For more than five decades, intervention through a series of plans and policies has been accepted as the most appropriate means of resolving the potential conflicts by theland-useand conservation agencies in Western Australia (Moir 1995).

TheDarling Rangehas been a focus for tourism and recreation sincetheearly $20^{\text {th }}$ century (Ingram 
and Hughes 2009). A 1977 report on public access to water catchments in the Southwest of Western Australia noted that access was mainly related to 'passive pursuits' including: tourism, barbeques, picnics, photography and 'nature study' (A dvisory Committee on Purity of Water 1977: 2). A later reportincluded an expanded list of moreactive pursuits including many water-based activities such as canoeing, water skiing, white water racing, rowing, power boating, fishing and swimming (Martinick and A ssociates 1991). A 2001 report on tourismand recreation included 13types of waterbased and land- based active and passive recreational activities (Muench, 2001). Finally, a report published in 2009detailed 20 different types of tourism and recreation activities across the Darling Rangearea (Hughesand Ingram 2009). The pattern shows that over time, both the types of activity and the number of people accessing the Darling Range for tourism and recreation have increased significantly. In this regard, recreation and tourism is an important occupancy mode in theDarling Range.

\section{Method}

This paper presents some of the results from two pieces of research on land management and recreation and tourism access in the Darling Range area. These were a desktop research exercise reviewing Western Australian Iand access legislation and policy and aseries of interviews with recreation user groups (Hughes et al. 2010; Hughes and Ingram 2009). Theaims of the research were: to identify the main issues regarding access to public land in theDarling Rangefor tourismand recreation; the perceived extent of any problems emanating from such access; and theextent to which both the access levels and any resultant problems were influenced by the policy and management environment.

\section{Review of Legislation and A ccess to Land}

A desktop literaturereview of thedocumented legislative and management contexts for managing access to land in Western A ustralia and specifically in the Darling Rangewas conducted in 2010. Online resources, reports, and academic publ ications were used. In addition to reviewing the literature, legislation and government documentation on landuse management, 15 representatives from the various stategovernment agencies responsiblefor managing land wereinterviewed over the courseof theresearch. Theseincluded senior managers and middle management staff responsible for formulating policy and implementing land-use management regimes. This phase provided information on thepolicy and management context in terms of legislative, policy and access management responsibilities associated with the Darling Rangearea.

\section{Tourism and Recreational Land U se}

This component of the research gathered data about recreational and tourist use of the Darling Range. Various Perth based recreation clubs and association representatives participated in in-depth interviews regarding when, where and how they accessed and used the area. A total of 80 representatives of various recreation and tourism clubs and associations based in the Perth region were interviewed over the course of the research betwen 2009 and 2011 . This information gathering exercise included face-to-face interviews with representatives based on asemi-structured interview format using open-ended questions to obtain opinions about recreation and tourism access (Table 2). Public land managers were also interviewed regarding their management of public access to land for tourism and recreation. E-mail conversations were used to gather supplementary information.

The following section discusses the findings from the desktop review and the interviews with land managers and recreation and tourism user groups.

\section{Land M anagement and Policy Perspectives}

The modern era of public land management in Western A ustralia arguably began in 1984 with theestablishment of the Department of Conservation and Land Management (CALM), mandated by the CALM Act (1984). The CALM Act (1984) represented a shift towards a more integrated 
Table 2. Recreation and Tourism Use Interview Summary

\begin{tabular}{|l|}
\hline Historic and Current Use, Future Concerns \\
\hline Historical tourism and recreation access \\
\hline Locations that were used but are no longer in use for the \\
activity \\
The main reasons for unused or changed locations \\
\hline Current tourism and recreation access \\
\hline Location or areas of various types of access and \\
activities \\
Times (seasons) of the year when access occurs \\
Frequency of access for the respectiveactivities \\
\hline Potential future tourism and recreation access issues \\
\hline \begin{tabular}{l} 
Issues of concern relating to access and activities \\
management \\
Suggestions for future management \\
\hline $\begin{array}{l}\text { Positive and N egative Experiences in Relation to Land } \\
\text { Access for Tourism and Recreation }\end{array}$ \\
\hline $\begin{array}{l}\text { Can you recall any positive experiences associated with } \\
\text { gaining access to land for tourism and recreation? }\end{array}$ \\
\hline $\begin{array}{l}\text { Can you recall any negative experiences associated with } \\
\text { gaining access to land for tourism and recreation? }\end{array}$ \\
\hline Thinking of your history of recreation and tourism \\
access to the Darling Range, do you think there have \\
been changes in access to land?
\end{tabular} \\
\hline
\end{tabular}

Source: Authors

approach to management of publicland in WA .Prior to this, responsibility for different public land-use modes was divided among various government agencies. CALM 's ancestry lies in the establishment of theWA Forests Department in 1916, a body with the prime responsibility of identifying and conserving forest areas for timber production. A series of local park reserves boards wereestabl ished during the early $20^{\text {th }}$ century with responsibility for public recreation and tourism access and the conservation of 'natural oddities' (Rundle1996).

A 1970 campaign by a consortium of WA conservation groupsfocused governmentattention on setting aside more land for conservation purposes. Consequently, in 1971, the WA State Governmentundertook a series of legislativereforms that led to the Environmental Protection Act 1973 (WA) and the establishment of a single entity for parks management in WA, the National Park Authority, in 1976 (Rundle 1996). A 1983 review of natural resourcemanagement wasthen undertaken by the state government with a view to making further reforms to bring about more efficient management. As a result, CALM was formed through the amalgamation of the Forests Department, the National Park A uthority and the wildlife component of the Department of Fisheries and Wildlife, as mandated by the Conservation and Land Management Act (1984). The CALM Act included a mandate for conservation of nature, providing public access to naturefor recreation and tourism, and management of forests for timber production as a means of more integrated management.

Since 1984, the Department of CALM has been significantly restructured twice In 2000, theforestry production element of CALM was separated out to becometheForestProducts Commission. Atthetime it was perceived by conservation advocates that the management of the forests by a single agency for both timber production and conservation was a conflict of interest. The al ternative view was that having oneagency responsiblefor timber production and conservation enabled moreeffectiveintegration of these activities as well as providing an income stream from logging that could fund conservation, recreation and tourism-related management and infrastructure(Shea personal communication 2002)

In 2006, CALM was amalgamated with the Department of Environment to become the Department of Environment and Conservation (DEC). Thenumber onestated key objective of DEC is biodiversity conservation whilethemanagement and facilitation of public recreational and tourist access to parks comes fourth among eight objectives, reflecting an increased focus on conservation as the preferred land-use mode (DEC 2007). The WA government is currently in the process of developing a Biodiversity Conservation Act that appears to include a slightly greater emphasis on tourism, recreation and Indigenous cultural land-usemodes, relativeto conservation imperatives. Thesechanges over timerepresent, in principle, a movetowards moreintegrated management of publicland through theestablishment of a singleagency with multiple responsibilities.

In terms of the Darling Range specifically, Table 3 outlines the main types of land-use types and management regime. 
Urban Fringe and Nature-based Tourism: Hughes et al.

Table 3. Primary Land-use Types and Public Access in the D arling Range Study A rea

\begin{tabular}{|l|l|l|l|l|l|}
\hline Land Type & $\begin{array}{l}\text { A rea (ha) } \\
\text { '000s }\end{array}$ & Tenure & $\begin{array}{l}\text { Occupancy } \\
\text { M ode }\end{array}$ & $\begin{array}{l}\text { Primary Land } \\
\text { Access M anager }\end{array}$ & Public A ccess Status \\
\hline Timber reserve & 1,300 & Public, Crown Land & Mixed use & DEC & Allowed \\
\hline $\begin{array}{l}\text { Conservation } \\
\text { reserve }\end{array}$ & 1,100 & Public, Crown Land & $\begin{array}{l}\text { Recreation } \\
\text { tourism and } \\
\text { conservation }\end{array}$ & DEC & $\begin{array}{l}\text { Allowed with some } \\
\text { restrictions and exceptions }\end{array}$ \\
\hline Privateland & 600 & Private & Mixed use & Land owner & $\begin{array}{l}\text { Not allowed without } \\
\text { owner's permission }\end{array}$ \\
\hline Active mining & 10.5 & $\begin{array}{l}\text { Public, } \\
\text { lease hold }\end{array}$ & Mixed use & Mine Lessee & $\begin{array}{l}\text { Not allowed without } \\
\text { Lessee's permission }\end{array}$ \\
\hline $\begin{array}{l}\text { Drinking water } \\
\text { protection zone }\end{array}$ & 463 & $\begin{array}{l}\text { Public Crown Land } \\
\text { and Private }\end{array}$ & $\begin{array}{l}\text { Water } \\
\text { conservation, } \\
\text { mixed use }\end{array}$ & $\begin{array}{l}\text { Water } \\
\text { Corporation }\end{array}$ & $\begin{array}{l}\text { Restricted in P2 and P3 areas } \\
\text { Not lowed in P1 areas }\end{array}$ \\
\hline $\begin{array}{l}\text { Declared Disease } \\
\text { Risk Area }\end{array}$ & $\begin{array}{l}\text { Approx. } \\
1,000\end{array}$ & Public & $\begin{array}{l}\text { Mixed use } \\
\text { DEC }\end{array}$ & $\begin{array}{l}\text { Restricted or no public } \\
\text { access, variable depending } \\
\text { on management }\end{array}$ \\
\hline
\end{tabular}

Sources: Australian Natural Resources Atlas (2009); DPI (2005), Forest Products Commission (2010) DEC (2010), Conservation Commission (2010), Dept Regional Development and Lands (nd)

Public (Crown) land in the Darling Range primarily includes areas managed for conservation, forestry reserves, water reserves and declared disease risk areas. Other areas are set aside for mining activities. Land reserved for conservation is managed by theWA Department of Environment and Conservation (DEC) for the benefit of thegeneral public, mandated by the CALM Act 1984 (WA), Environmental Protection A ct 1986 (WA) and Wildlife Conservation Act 1950 (WA). DEC managed lands include areas designated as national parks, nature reserves, recreation areas, conservation parks, and environmental parks and so on. These differentland-tenuretypesallow for a varying rangeof public activities.

Stateforests arepubliclands managed by DEC and the Forest Products Commission primarily under the CA LM Act 1984and Forest Products Act 2000 for the purposes of timber production. State forests are open to public access for recreational purposes except in areas wherelogging is activeor specific management regimes or zonings are overlaid. Such overlays can includeland designated as special conservation zones, water protection zones or disease risk areas.

Private land generally includes freehold urbanized land, agricultural properties, hobby farms or privately held holiday homes. Publicaccess to private land is at the landowner's discretion. Privatelandownersin WA haveatradition of control of access and a strong belief in the exclusivity of their rights to manage their property without interference. Staley (2006) argued that private landowners are feeling increasingly threatened by government imposed restrictions and controls in WA. There is also a general strong sense of exclusivity and a reticence to allow public access for recreation due to perceived risk and liability similarly observed by Jenkins and Prin (1998) and Booth (2006).

All of theland in the Darling Rangefalls under someform of mining exploration lease, though only a small portion of this is actively mined, mainly for bauxiteat thesouthern end of thestudy area (Figure 2 ), and for some other metal ores including gold. The principal bauxite mining lease covers 50-60\% of the Darling rangestudy area and most of thewater supply catchments. (Bari and Ruprecht 2002). However, the area of activemining involvesabout 550 hectares annually. Mining is restricted to state forest and is excluded from the conservation reserves. Bauxite mining is highly mobile and involves removing forestand up to $3 \mathrm{~m}$ of soil profile in isolated pods averaging about 20 ha but up to 100 ha. The mined areas are rehabilitated but do 
not return to the original ecological state with significantly altered topography, hydrology and biodiversity (Majer in press). Public access into actively mined leases is not allowed without the lessee's permission. Previously mined areas and areas under lease but yet to be mined are open to public access. The shifting character of bauxite mining and the reduce ecological quality of previously mined areas was identified by some recreation groups as reducing the quality of recreation and a disincentive to access in these areas.

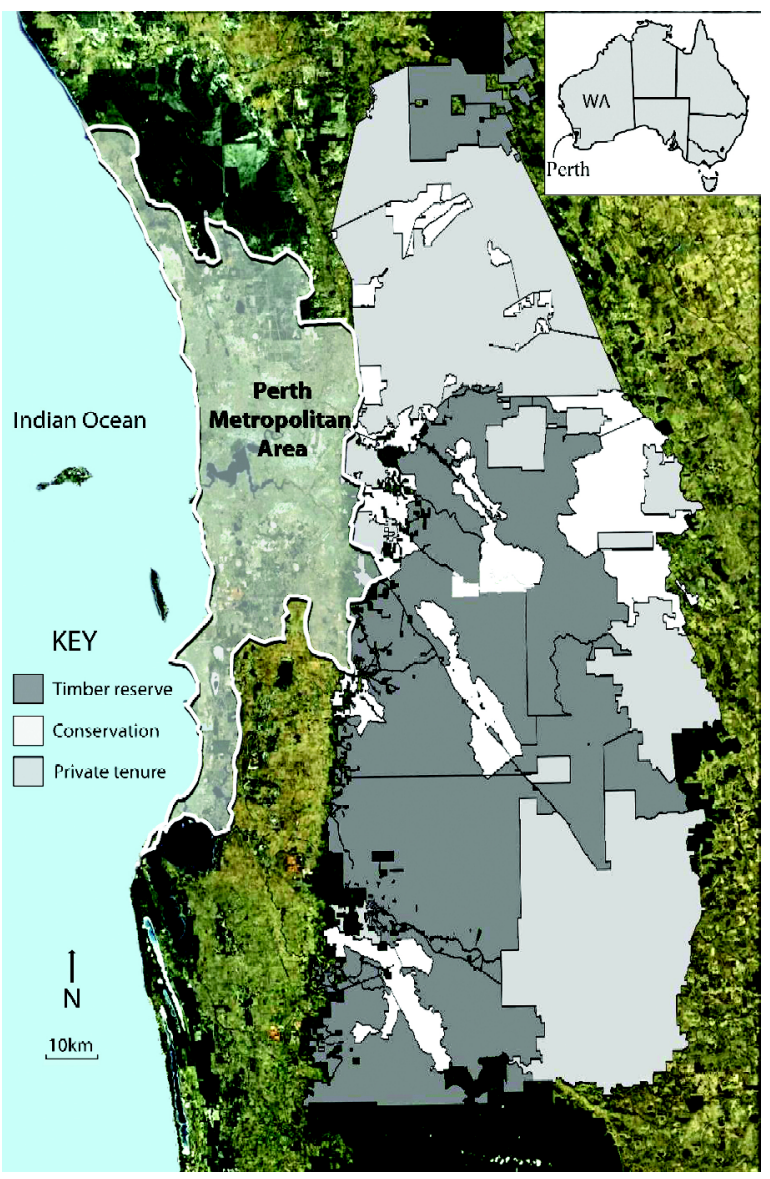

Figure 1. $M$ ap of the $D$ arling Range Study A rea Showing Private Tenure, Conservation Reserves and Timber Reserves

As part of its biodiversity conservation remit, DEC also manages land in the Darling Range for control of a soil-borne plant pathogen known as

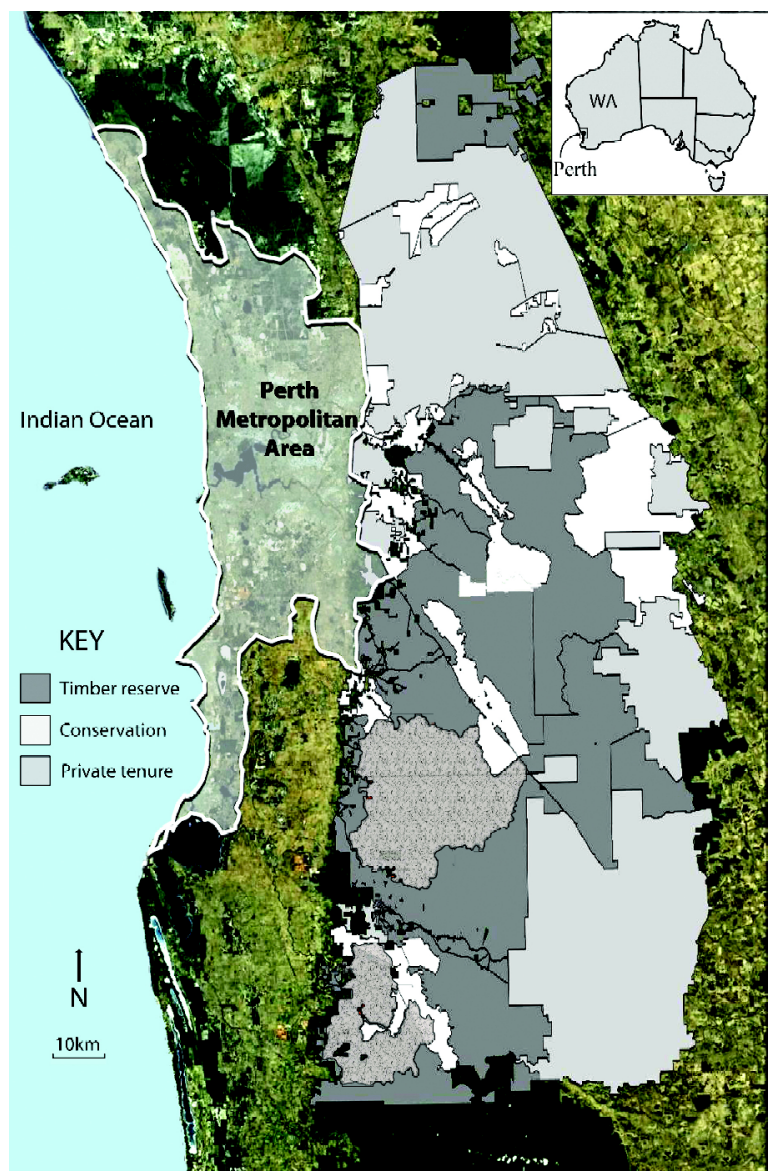

Figure 2. D arling Range Study A rea with an O verlay of the ActiveB Buxite M ining Leases

DieBack (Phytophthora cinnamomi) which attacksa range of plant species including the dominant Jarrah tree (Eucalyptus marginata) and thereby adversely effects the entire forest and woodland ecosystem. This pathogen can be spread by people or vehicles carrying infected soil from oneforested area to another. To manage the spread of the pathogen, part VII of the CALM Act 1984 and the Forest Management Regulations 1993(WA ) enable DEC to establish 'Disease Risk A reas' (DRAs) that restrict public access and certain activities within these areas (Figure 3). This can include banning vehicle and machinery access or a blanket ban on all public access for periods of time. The DRA can overlay other occupancy modeson public land. The current DRA includes a significant portion of the Darling Rangestudy area meaning that public access 


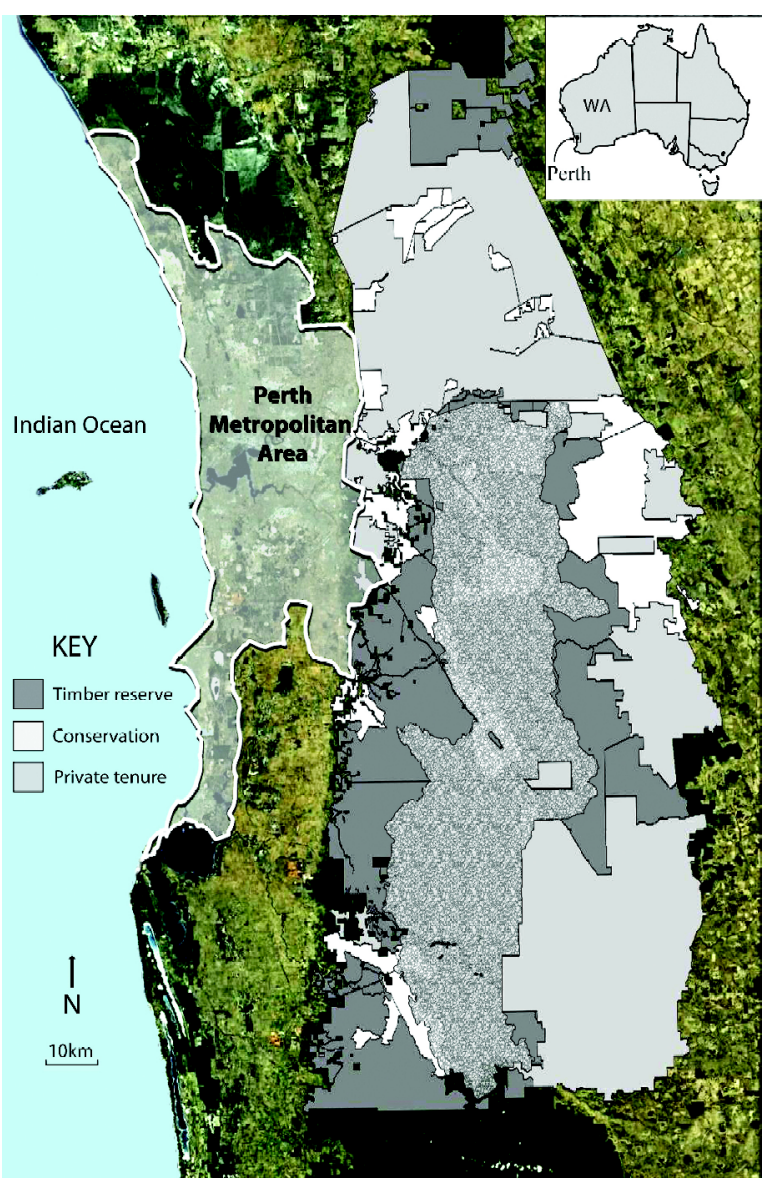

Figure 3. $D$ arling Range Study A rea with an O verlay of D isease Risk A reas as at 2010

is either restricted to certain activities or is excluded entirely. Thus DEC, as an amalgamation of various government agencies and responsibilities, is responsiblefor a broad and complex array of landusemanagement and occupancy modes.

In addition to DEC, another significant public land manager in the Darling Range region is the Department of Water which is responsiblefor policy regarding the management of public drinking water dams and catchments. Much of the Darling Range land is within public drinking water supply catchment areas where varying levels of public accessareallowed. TheDarling Rangeareaincludes ten dams that capturepart of thePerth M etropolitan Area's drinking water supply. These dams are located in a north-south linealong the eastern fringe of the metropolitan area. Each catchment is currently divided into three levels of access management priority. Priority 1 zones comprise an area with a radius of $2 \mathrm{~km}$ upstream of the dam wall whereall public access is excluded. The remaining priority 2 and 3 zones allow certain restricted forms of public access. These zones overlay state forest reserves, urban areas, agricultural areas, mining leases private land and conservation reserves. Water protection zones may be declared under the Metropol itan Water Supply Sewerageand Drainage Act 1909 and theCountry A reas Water Supply Act 1947 by the WA Department of Water and are managed by the quasi-governmentorganization, the Water Corporation. (Figure 4). Currently, state

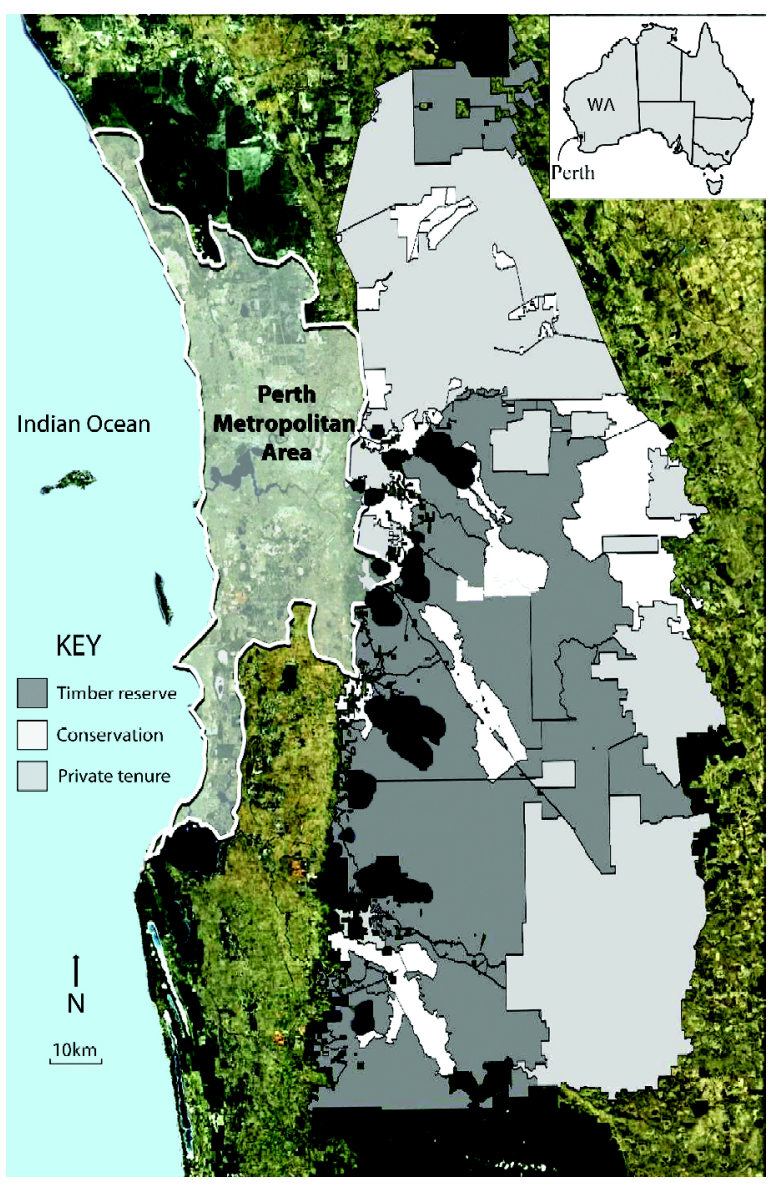

Figure 4. D arling Range Study A rea with an O verlay of the Priority one Exclusion Zones for D rinking Water Supply Protection 
regulations allow there-designation of thesezones under the Acts by the Department of Water, for water-related purposes, which can result in exclusion of public access for recreation and tourism from previously accessiblepublicland whileother activities such as mining and agriculture are allowed to continuein thesezones.

So, whilepublicland is plentiful in the Darling Rangearea, and is (in theory) managed by a single entity in the form of the state government, the government is divided within itself with regard to how the land is managed. This is despite efforts to integrateland management through amal gamation of government agencies and responsibilities. However, two key agencies with responsibility for managing themajority of publicland in the Darling Range, DEC and Department of Water aremandated by different, and often conflicting, legislation. For example, it would seem that DEC, as the principal land manager is aligned morewith Urquhart et al. (2012) 'Multifunctional' and 'Custodian' landowner types. These types of landowners are interested in conservation and resourceextraction, but arealso open to public access for recreation and tourism under certain preconditions. This is particularly so for the 'multifunctional' landowner approach, while 'custodians' are more wary about public access, based on their concerns for conserving natural habitats. The Department of Water seems morealigned with thevalues of the 'custodian' and 'individualist' land manager.

While these categorized landowner types occupy and control discretepockets of privateland in regions such as theUK, US and Europe, thereby creating afixed mosaic of land-uses, theWA context is more complex. This is because the various management approaches are applied as policy jurisdictions that can overlap and change at short notice. For example, land managed for recreation and tourism by DEC can be overlaid with water catchment protection zones, DRAs and/ or mining leases. Figure 5 provides a combined overlay of the variousoccupancy modesillustrated in Figures 1, 2 and 3, demonstrating theoverlaps between DRAs, water protection zones, mining, conservation, timber production and theresidual DEC tenurein the Darling Range study area. The combinations

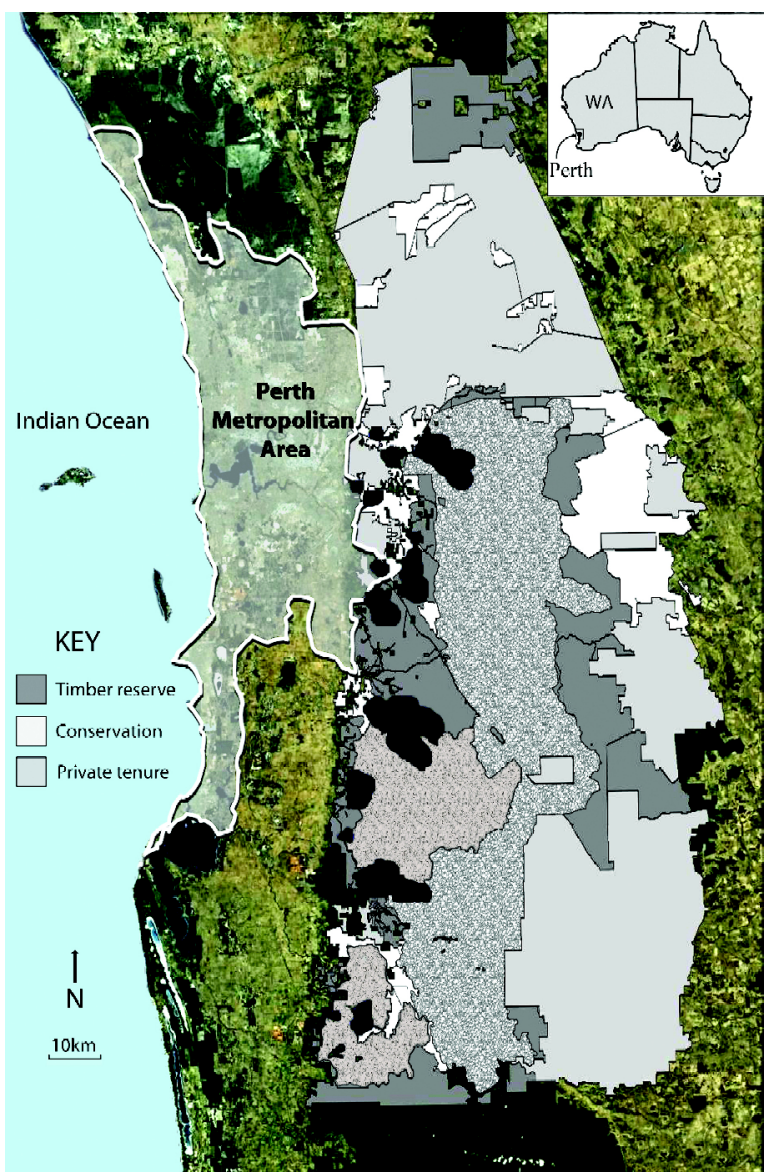

Figure 5. D arling Range Study A rea with an Overlay of DRA, M ining and W ater Protection Zones

and intersections of these management regimes result in a majority of the public land exhibiting either restricted publicaccess or completeexdusion of public access for recreation and tourism.

In addition, policies and management and the land areasto which they areapplied in theDarling Range can change, either gradually or rapidly (Hughes and Ingram 2010; H ughes et al. 2008). For example, an area of forestmay be dosed to recreation and tourism access at short notice if it is declared a DRA. A lternatively, an area of forest may haveits DRA management status downgraded thereby allowing public access. A sanother example, a water reservoir that is solely used for irrigation supply may beused for land-and water-based tourism and 
recreation activities. If that reservoir then has a portion of its water al located to the urban drinking water supply, all tourism and recreation activities are totally excluded within $2 \mathrm{~km}$ upstream of the water body in order to protect water quality. This situation can occur at short notice (see for example, Hugheset al. 2008). Furthermore, whilePriority One water protection zones prohibit public access for tourism and recreation, they may overlap with mining areas, agriculture and timber production areas. Mining, agriculture and timber harvesting are permitted to continue in these circumstances while, paradoxically, tourism and recreation are excluded to protect water quality. Thisfluid state of policy and management combined with the overlapping jurisdictions causes tensions between and within government agencies as to which land occupancy mode should take primacy and what should be allowed when and where. This also causes confusion for the public as to when and where they can access land for which forms of tourismand recreation.

\section{Tourism and Recreation Users' Perspectives}

Interviews with recreation clubs and associations (80 interviews) documented 13general types of recreation and tourism activity which were widely distributed across thelength and breadth of theDarling Range. Many of theseactivitiesincluded several sub-categories. For example, mountain biking included down-hill, cross-country and longdistanceriding. Bushwalking included day walks, extended overnight walks and on-track and off-track hiking. Four wheel driving included day trips, extended overnightexcursions, and preferencesfor access to a range of terrain from rough to mild. This indicates not justa diversity in terms of therange of recreation and tourism activity types, but also diversity within each type in terms of public expectations and requirements.

In terms of what types of land are accessed, theinterview respondentsindicated that they most commonly accessed conservation reserves (86\%), state forest (timber) reserves (84\%) and water protection reserves (58\%). Interestingly, a significant number also indicated they regularly accessed privateland (51\%). Only a small fraction indicated access to mining reserves (7\%). Theseresults show that most recreation and tourism activity undertaken in the Darling Range by Perth-based groups is primarily on public land managed for either conservation, water production or timber production. That is, these groups commonly use land set aside for production and conservation as well as recreation and tourism.

When asked to recall positive experiences associated with the process of gaining access to land for tourism and recreation, about $64 \%$ of respondents could do so, while $14 \%$ could not. When asked whether they could recall any negative experiences, about $33 \%$ could, while $42 \%$ could not. Further investigation revealed that the positive experiences tended to beassociated with personal interactions with individual government agency staff (such as park rangers) as part of an informal, independent recreation and tourism experienceon publicland. Alternatively, positiveexperiences were associated with relationships built up between recreation and tourism groups and individual privateland holders. Negativeexperiencestended to beassociated with organizational and systemic issues regarding access to public land. Negative experiences were also mainly associated with obtaining permission for organized group activities and events on publicland. This explains the higher proportion of people able to recall positive experiences because obtaining informal and independent access was a more common type of activity than was seeking access for organized large group events.

Commonly, there was confusion regarding which authority to approach for a permit to conduct organized group activities such as orienteering, rogaining and endurance horse riding events that tend to range acrosslargeareas of publicland. These types of organized events includea combination of peopleinvolved in competitivemulti-day activities and spectators who travel to the region and stay overnight. Interviews revealed that the process of gaining permission for such access generally took an extended length of time and required formal approval from several different government representatives. Some of theland manager decisions 
contradicted each other in terms of allowing or forbidding certain types of access to given areas.

Interviewsindicated that therewas a common concern about the difficulties associated with accessing land for recreation and tourism with regard to theinconsistent and often contradictory decision-making processes that these groups and individuals encountered. Their frustrations were exacerbated when thejurisdictions of differentstate government agencies overlapped, such as occur between DEC and the Department of Water.

Ultimately, the publicly-owned land in the Darling Range is managed by a singleland owner in theform of thestategovernment, primarily DEC and theDepartment of Water. H owever, in practice, thegovernment landowner encompasses the whole range of Urquhart et al.'s (2012) landowner types. Unlike private land owner types that are tied to discrete areas of land, the Darling Range has a shifting, overlapping and often contradictory maze of public land occupancy policies and management regimes. Interestingly, and perhaps somewhat ironically, from the recreation and tourism users' points of view, many opted to access privateland, with permission from the land owners. This was becausegaining permission to use privateland for organized recreation and tourism activities was often considered to beeasier than gai ning access to public land for thesamepurpose. This easeof access was mainly associated with having to approach onelandowner for privateland, rather than multiple land managers to access public land.

\section{Conclusion}

Past research on access to the Darling Range has highlighted both the benefits of and the high demand for recreation and tourism access to the Darling Range area for a range of land uses (Advisory Committee on Purity of Water 1977; Hughes and Ingram 2010; Hughes et al. 2008; Martinick and Associates 1991; Muench 2001). However, it has also noted the tensions between tourismand recreation user groupsand public land management agencies and thetensions within these agencies (Hall 2011; Haukeland 2010).
Despite efforts to integrateland management through amal gamation and legislativechanges over several decades, the state government still lacks consistency in its approaches to recreational and touristaccess to itsland. This is becausetheprimary government land manager (DEC) is responsiblefor a complexity of land management and use issues but appears to havea lack of corporatecontrol. Asa result, decisions made at the local level can vary from place to place. Furthermore, as Iand management in the Darling Range also includes different government agencies with overlapping jurisdictions and often conflicting mandates based on their governing legislation. Theaccess regimes of areas of land that fall under theresponsibility of specific agencies can change, depending on shifts in policy and legislation. This circumstance is exacerbated by a lack of clarity over which land management mandate should take precedence in any given area or situation. This leads to the somewhat ironic circumstance whereby some tourismand recreation groups wanting to organize group events approach private landholders for permission to access their land becausethis is easier and simpler to achieve relative to obtaining all relevant public land access permissions.

It must also beacknowledged that someland uses, including some tourism and recreation activities, that demand access to the same or adjoining spaces are, in some cases, incompatible. For example, hikers, mountain bikers, off-road motorcyclists, four-wheel drivers and endurance horse riders are just some of the groups currently vying for the samerecreational spaces. Competition by various types of tourism and recreation activities as well as by a broader suite of other land users in the Darling Range has resulted, to date, in conflicting management regi mes and, as a result of this, in uncertainty over access rights. This is exacerbated by the recreation and tourism user groups perceptions regarding rights of access based on a long tradition in connection to public land (Williams 2001).

Hall and Jenkins (1998), Hultman et al. (2011) and U rquhart et al. (2012) comment that peri-urban recreation and tourism has achieved greater 
Urban Fringe and Nature-based Tourism: Hughes et al.

recognition as an important land use by managers and policy-makers over recent decades. However, this case demonstrates that while it may be recognized as significant, it is often relegated to a lower priority of importance and faces inconsistencies in management on the ground.

It seems that, in this instance, an integrated approach to multifunctional land-use is yet to be effectively achieved despiteat least three decades of work towards this goal. As noted in the literature, effective management would ideally include the engagement of both the various government agencies and the community-based organizations and industries with interests in accessing natural areas for various types of activity (Mitchell and Hollick 1993; Hall 2011). To achievethis end, thesharing of resources, mutual influence, transparency, commitment, trust and respect, active participation and accountability through cross-sectorial interactions over an extended period of time is an ideal approach (Laing et al. 2008a; Laing et al. 2008b).

In the case of the public land managed by government in WA, this is undermined by a lack of consistent decision-making by DEC at thelocal leve, alack of effectivecooperation between DEC and the
Department of Water and a lack of trust or perhaps respect between recreation usersand land managers at theorganizational level. This is a function of the social and political history of these agencies with land management traditions focusing variously on protection, production and consumption.

It would appear that the perception by recreation and tourism user groups that opportunities for access are being restricted on publicland aretrueto a certain extent, but perhaps mainly owing to perceived and real power differentials (Hall 2011) and a lack of truly integrated management rather than an general drive to exclude this type of land use. This is combined with a shifting matrix of complex land management priorities and a perception by interviewed users of the right to access public land for recreation and tourism (Williams 2001). It appears that a cultural shift is required morethan changes in management structure, legislation and policy. In the mean time, thereis irony in WA with its wealth of public land butatendency for tourism and recreation groups to approach individual privatelandholders for some types of access (usually organized events), rather than navigatethecomplex and shifting bureaucracy associated with accessing public land in many instances.

\section{References}

ABS (2012). Regional Population Growth, Australia, 2011: Western Australia. Available at http:/ / www.abs.gov.au - Accessed on 15 November 2012.

ADVISORY COMMITTEE ON PURITY OF WATER (1977). A Study of Catchments and Recreation in Western Australia. Perth, WA. Government of Western Australia.

AUSTRALIAN NATURAL RESOURCES ATLAS (2009). Land Use - Australia. Available at http:/ / www.anra.gov.au/ topics/ land/ landuse - Accessed on 10 June 2010.

BARI, M. and RUPRECHT, J. (2002). Water Yield Response to Land Use Change in South-West Western Australia. Report for the D epartment of Environment. Perth. Government of Western Australia.

BOOTH, K. (2006). Public Rights of Access to the Countryside (PhD Thesis). New Zealand. University of Otago.

BUTLER, R., HALL, C. M. and JENKINS, J. (1998). Introduction. In Butler, R., Hall, C.M. and Jenkins, J. (Eds) Tourism and Recreation in Rural A reas. Chichester, UK. John Wiley \& Sons: 3-16.

CONSERVATION COMMISSION (2010). Annual Report 2009-10. Available at http:/ / www.conservation.wa.gov.au/ - Access on 15 November 2012.

DEC (2007). WA Department of Environment and Conservation Corporate Plan 2007-2009. A vailable at http:/ / www.dec.wa.gov.au - Accessed on 20 November 2012.

DEC (2010). Management and Protection. A vailable at http:/ / www.dec.wa.gov.au - Accessed on 20 November 2012.

DEPARTMENT OF REGIONAL DEVELOPMENT AND LANDS (nd). State Lands. Available at http:/ / rdl.wa.gov.au Accessed on 10 June 2010.

DPI (2005). Crown Land Management. Available at http:/ / www.dpi.wa.gov.au/crown_management0905.pdf - Accessed on 20 November 2012. 
Urban Fringe and Nature-based Tourism: Hughes et al.

FOREST PRODUCTS COMMISSION (2010). Native Forests: South West. Available at http:/ / www.fpc.wa.gov.au - Accessed on 20 November 2012.

GARROD, B., WORNELL, R. and YOUELL, R. (2006). Re-coneptualising Rural Resources and Countryside Capital: The Case of Rural Tourism. Journal of Rural Studies 22: 117-128.

HALL, C. M. (2011). A Typology of Governance and its Implications for Tourism Policy Analysis. Journal of Sustainable Tourism 19(4\&5): 437-457.

HULTMAN, J., HALL, C. M. and GOSSLING, S. (2011). Tourism Mobility, Locality and Sustainable Rural Development. In Macleod, D. and Gillespie, S. (Eds) Sustainable Tourism in Rural Europe: A pproaches to D evelopment. Milton Park, UK. Routledge: 28-42.

HAUKELAND, J.V. (2010). Tourism Stakeholders' Perceptions of National Park Management in Norway. Journal of Sustainable Tourism 19(2): 133-153.

HOLMES, J. (2006). Impulses Towards a Multifunctional Transition in Rural Australia: Gaps in the Research Agenda. Journal of Rural Studies 22(2): 142-160.

HUGHES, M. and CARLSEN, J. (2009). Developing a Knowledge Platform on Value of Parks for Tourism. Proceedings of the BEST EN Think Tank IX: The Importance of Values in Sustainable Tourism. James Cook University. Singapore, June 15-18, 2009.

HUGHES, M. and INGRAM, C. (2009). Where People Play: Recreation in the Southern D arling Range, W estern Australia. Perth, Western A ustralia. Department of Sport and Recreation.

HUGHES, M. and INGRAM, C. (2010). Recreational Access to Urban Water Supplies. In Crase, L. and O'Keefe, S. (Eds) Water Policy, Tourism and Recreation. New York. RFF Press: 132-147.

HUGHES, M., TYE, M. and ZULFA, M. (2010). The Right to Roam: A Review of Policy and M anagement of Public Access to Land. Perth, Western Australia. Department of Sport and Recreation.

HUGHES, M., ZULFA, M. and CARLSEN, J. (2008). A Review of Recreation in Public Water Catchments in the Southwest Region of Western A ustralia. Perth, Western Australia. Department of Sport and Recreation and Department of Environment and Conservation.

INGRAM, C. and HUGHES, M. (2009). Where People Play: Recreation in the Southern D arling Range, Western A ustralia. Perth WA. Report for the WA Department of Sport and Recreation.

JENKINS, J. M. and PRIN, E. (1998). Rural Landholder Attitudes: The Case of Public Recreational Access to 'Private' Rural Lands. In Butler, R., Hall, C.M. and Jenkins, J. (Eds) Tourism and Recreation in Rural A reas. Chichester, UK. John Wiley \& Sons: 179-196.

JENNINGS, G. (2007). Water-based Tourism, Sport, Leisure and Recration Experiences. Burlington, USA. Elsiever.

LAING, J., WEGNER, A., MOORE, S. and WEILER, B. (2008a). Identifying Success Factors Behind Partnerships for Managing Recreation and Tourism in Urban Fringe Parks. A nnals of Leisure Research 11(1\&2): 101-122.

LAING, J., WEGNER, A., MOORE, S., WEILER, B., PFUELLER, S., LEE, D. and LOCKWOOD, M. (2008b). U nderstanding Partnerships for Protected A rea Tourism: Learning from the Literature. Gold Coast, Australia. Sustainable Tourism CRC.

MANN, C., POUTA, E., GENTIN, S. and JENSEN, F. (2010). Outdoor Recreation in Forest Policy and Legislation: A European Comparison. U rban Forestry and U rban Greening 9(4): 303-312.

MAJER, J. (in press 2013). Mining and Biodiversity: Are They Compatible? In Brueckner, M. and Pforr, C. (Eds) Resource Curse or Cure? New York. Springer.

MARTINICK AND ASSOCIATES (1991). A Review of the Water Based Recreation in Western Australia. Perth, WA: Ministry of Sport and Recreation and Western Australian Water Resources Council.

MCINTYRE, N., JENKINS, J. and BOOTH, K. (2001). Global Influences on Access: The Changing Face of Access to Public Conservation Lands in New Zealand. Journal of Sustainable Tourism 9(5): 434-450.

MILLWARD, H. (1991). Public Recreational Access in the Countryside: Concepts and Measures of Physical Rigour. Journal of Rural Studies 7(3): 241-251.

MOIR, J. (1995). Regional Parks in Western Australia. A ustralin Planner 32(2): 88-95.

MUENCH, R. (2001). Southern D arling Range Regional Recreation Study. Perth, WA: Department of Conservation and Land Management, Water Corporation and Water and Rivers Commission.

NEWSOME, D., MOORE, S. and DOWLING, R. (2002). N atural A rea Tourism: Ecology, Impacts and M anagement. Clevedon. Channel View Publications.

PIGRAM, J. and JENKINS, J. (1999). O utdoor Recreation M anagement. London. Routledge.

RUNDLE, G. (1996). History of Conservation Reserves in the South-west of Western Australia. Journal of the Royal Society of Western Australia 79: 225-240.

SHEA, S. (2002). Forest Management and Water Catchments. (personal communication) March 15, 2002. University of Notre Dame, Fremantle, Western A ustralia. 
Urban Fringe and Nature-based Tourism: Hughes et al.

STA LEY, L. (2006). Property Rights in Western Australia: Time for a Changed Direction Occasional Paper presneted at the Institute of Public Affairs, WA Australia.

URQUHART, J., COURTNEY, P. and SLEE, B. (2012). Private Woodland Owners Perspectives on Multifunctionality in English Woodlands. Journal of Rural Studies 28: 95-106.

WELLER, R. (2009). Boomtown 2050: Scenarios for a Rapidly Growing City. Perth, Western Australia. UWA Press.

WILLIAMS, D. (2001). Sustainability and Public Access to Nature: Contesting the Right to Roam. Journal of Sustainable Tourism 9(5): 361-371.

WILLIAMS, A. and SHAW, G. (2009). Future Play: Tourism, Recreation and Land Use. Land U se Policy 265: S326-S335

WILLIAMSON, K. and MITCHELL, D. (2001). Jarrah Forest: JF1 (Northern Jarrah Forest Subregion). A Biodiversity A udit Report of Western Australia's 53 Biogeographical Sub-regions in 2002. Report for the WA Conservation Commission. Perth, Government of Western Australia.

Submitted: December 3, 2012

Accepted: February 5, 2013 